\title{
Moving Students to Deeper Learning in Leadership
}

\author{
Sheri Stover \\ Associate Professor \\ Wright State University \\ Corey Seemiller \\ Assistant Professor \\ Wright State University
}

\begin{abstract}
The world is a volatile, uncertain, complex, and ambiguous (VUCA) environment (Carvan, 2015) that calls for leaders who can effectively navigate the complexity of leadership today. Students of leadership studies must not only learn leadership information content, but also be able to effectively implement the content and process, requiring deep approaches to their learning (Petrie, 2014). This quantitative research study used the ASSIST Inventory to measure approaches to learning (surface, deep, or strategic) for students enrolled in an Organizational Leadership undergraduate program. Students showed a preference for deeper approaches, though, many continue to use surface approaches, which may lead to shallow understandings and the inability to put content into practice. Specific strategies are provided for instructors to help students move toward deeper approaches.
\end{abstract}

\section{Introduction}

With countless issues across every societal sector needing effective leadership compounded with story after story of bad leaders (Kellerman, 2004), it is no wonder that there has been an increase in leadership studies programs in higher education (Brungardt, Greenleaf, Brungardt, \& Arensdorf, 2006). Are these leadership studies programs really preparing students to lead in what Carvan (2015) calls a volatile, uncertain, complex, and ambiguous (VUCA) environment? Leadership Studies programs must prepare their students to take deeper approaches to their learning so that these students are prepared to develop creative and innovative solutions needed to solve the complex issues of the twenty first century (Chan, $\mathrm{Fu}$, Schumm, Cagan, Wood, Kotovsky, 2011).

In 2014, the Center for Creative Leadership published a collection of thoughts from leadership experts about the trends for the future of leadership development. These experts asserted that leadership education needs to move from horizontal development where students learn through surface learning approaches by memorizing content from an expert source such as a professor to vertical development where students move through "states" to progress toward performing at higher levels and in more complex environments (Petrie, 2014). Roberts (2007) adds that students must engage in deep learning in leadership, which involves conducting critical self-examinations, questioning the conduct of themselves and others, engaging in substantive interactions, and reflecting on the impact of leadership actions. Leadership studies professional organizations such as the Association of Leadership Educators (Andenoro et al., 2013) and the International Leadership Association (ILA, 2009) are also calling for leadership studies programs 
to ensure that their students take deep approaches to learning.

\section{Literature Review}

Students' approach to learning can be defined as "the ways in which students go about their academic tasks, thereby affecting the nature of the learning outcomes" (Biggs, 1994). Educational research has identified three approaches to learning: (1) surface, (2) strategic, and (3) deep (Entwistle, McCune, \& Walker, 2001), each outlined in Table 1.

The strategy behind a surface learning approach is to learn the bare essentials through rote memory instead of seeking meaning (Biggs, 1987). Students will memorize bits of content in the course as unrelated knowledge, focus on meeting the minimum requirements in the syllabus, study without reflection on purpose or strategy, and feel pressure and anxiety about their efforts (Entwistle \& Peterson, 2004). The aim is to not work too hard, yet avoid failing.

The strategic approach involves trying to earn the best possible grades by organizing time efficiently, evaluating study effectiveness (Entwistle, 2000), and developing processes to maximize assessments and grading (Pintrich \& Garcia, 1991; Vermunt, 1998). Strategic learners are driven by competition to obtain the highest grade in a course and will use both the deep approach and the surface approach when they feel it gives them a competitive advantage. 
Table 1

Approaches to Learning

Surface approach to learning

- Treating the course as unrelated bits of knowledge

- Memorizing facts and carrying out procedures routinely

- Finding difficulty in making sense of new ideas presented

- Seeing little value or meaning in either courses or tasks set

- Studying without reflecting on either purpose or strategy

- Feeling undue pressure and worry about work

Deep approach to learning

- Relating ideas to previous knowledge and experience

- Looking for patterns and underlying principles

- Checking evidence and relating it to conclusions

- Examining logic and argument cautiously and critically

- Being aware of understanding developing while learning

- Becoming actively interested in the course content

Strategic approach to learning

- Putting consistent effort into studying

- Managing time and effort effectively

- Finding the right conditions and materials for studying

- Monitoring the effectiveness of ways of studying

- Being alert to assessment requirements and criteria

- Gearing work to the perceived preferences of lecturers

(Entwistle, McCune, \& Walker, 2001)

A deep approach to learning involves seeking to transform knowledge by understanding the meaning behind the text and making connections to prior experiences (Marton, Hounsell \& Entwistle, 1997; Marton \& Säljö, 1976). Deep learners develop interest and competence in the course. They read extensively and attempt to make connections with their previous applicable content knowledge (Biggs, 1987). Students using the deep approach thrive on intellectual challenge (Entwistle \& Peterson, 2004) and strive to understand ideas for themselves (Entwistle, McCune, \& Walker, 2001).

Marton and Säljö (1976) found that students using deeper approaches to learning were better able to grasp an author's message while students using surface approaches had higher levels of miscomprehension. Several subsequent research studies have confirmed that students using deeper and strategic approaches to learning result in better learning, and students using surface approaches to learning result in lower performance (Byrne, Flood, \& Willis, 2004; Duff, 2004; May, Chung, Elliot, \& Fisher, 2012).

Despite the notion that most university instructors prefer students use a deep approach to learning, many students continue to use surface approaches (Andrews, Garriso, \& Magnusson, 2006). Why, though, do they use surface approaches? First, many college classes are taught using a lecture format with multiple-choice memorization assessments emphasizing knowledge 
transmission. This type of course delivery and assessment aligns well with a surface approach in that students learn what they need from the information presented to pass the test (Stanger-Hall, 2012). Second, many courses are organized so that each textbook chapter is taught in an independent silo, which makes it difficult for students to make connections between the topics, resulting in learning in a vacuum (Wiggins \& McTighe, 2011). Finally, with multiple commitments to tend to, students engage in surface learning simply to do the bare minimum to pass their courses (Biggs, 1999; Prosser \& Trigwell, 1999), especially because using a surface approach can still result in earning high grades.

\section{Research Questions}

This research study addresses the following research questions:

1. Research Question 1: What is the most preferred approach to learning for students in an undergraduate Organizational Leadership program?

2. Research Question 2: Is there a relationship between students' self-reported cumulative GPA and students' approach to learning?

3. Research Question 3: Is there a relationship between a student's score on their strategic approach to learning and their score for deep or surface learning?

\section{Methodology}

This quantitative research study was conducted at a medium-sized Midwestern university with students enrolled in an undergraduate Organizational Leadership program. The survey was administered in 19 classes, with a total enrollment of 429 students. Students taking multiple classes were asked to complete the survey only once, resulting in 232 students who completed the Approaches to Study Skills Inventory for Students (ASSIST). The ASSIST is a quantitative survey developed to assess students' predominant approach to learning (Tait, Entwisle, \& McCune, 1998). The ASSIST survey includes 52 statements designed to measure students' approaches to studying with 16 statements that specifically measure the deep approach, 20 that measure the strategic approach, and 16 that measure the surface approach. For each of the 52 statements on the inventory, students are asked to select one of the following responses: (1) Strongly Disagree, (2) Disagree, (3) Unsure, (4) Agree, and (5) Strongly Agree. The measurements are clustered into 13 sub-scales listed in Table 2. Several studies using the ASSIST Inventory have shown high coefficents of reliability between 0.80 to 0.87 (CRLI, 1997; Entwisle, Tait, \& McCune, 2000). The ASSIST Inventory (Tait et al., 1998) was slightly modified for this study to include verbiage more appropriate for an American audience instead of British students (i.e. tutor was changed to instructor). 
Table 2

ASSIST Inventory Sub-Scales

\begin{tabular}{llll}
\hline Deep Approach & & \multicolumn{1}{c}{ Strategic Approach } & \multicolumn{1}{c}{ Surface Approach } \\
\hline 1) Seeking meaning & 1) Organized studying & 1) Lack of purpose \\
2) Relating ideas & 2) Time management & 2) Unrelated memorizing \\
3) Use of evidence & 3) Alertness to assessment demands & 3) Syllabus-boundness \\
4) Interest in ideas & 4) Achieving & 4) Fear of failure \\
& 5) Monitoring effectiveness & \\
\hline
\end{tabular}

Tait et al., 1998

The survey was administered using pre-printed scantron sheets where students could anonymously record their responses to the measurements. Completed scantron forms were processed, and the raw data were saved into an Excel spreadsheet. Cases that were missing more than 5\% of the data were removed (Dong \& Peng, 2013). In addition, cases without estimated GPA and the three that were outliers were removed, resulting in 191 records. The cleaned data file was uploaded to SPSS for data analysis. Cronbach's alpha was used to test the internal consistency for each scale. The Cronbach's alpha for Deep Approach $(\alpha=.78)$, Strategic Approach $(\alpha=.88)$, and Surface Approach $(\alpha=.82)$ indicated a good level of internal consistency (DeVellis, 2012).

The majority of students who participated in the study were male $(n=101)$ compared to female $(n=90)$. Students had a range of academic classifications from Sophomore $(n=14)$, Junior $(n=64)$, and Senior $(n=113)$. The majority of students identified their age as 22-25 $(n=$ 76). Other age selections included 17-21 $(n=55), 26-30(n=19), 31-40(n=20), 41-50(n=12)$, and 51-60 $(n=8)$.

\section{Results}

RQ1: Preferred Approach to Learning. The first research question focused on students' preferred approach to learning. The descriptive statistics associated with students' approaches to learning are reported in Table 3. Students responded to items on a 1 to 5 Likert scale (with 5 being the highest). The scores for the three approaches to learning (deep, strategic, and surface) were determined by adding up the sub-scale scores that contributed to each approach. Total scores for each approach were determined for deep approach $(M=57.78 ; S D=$ $7.24)$, strategic approach $(M=74.71 ; S D=10.59)$, and surface approach $(M=48.58 ; S D=9.46)$. The highest possible score for each approach varied $($ deep $=80$, strategic $=100$, surface $=80)$, so the scores were calculated on the average responses to questions to equate a score that is comparable for all three approaches. The learning approach that students used most often was the strategic approach $(M=3.74 ; S D=.53)$, followed by the deep approach $(M=3.61 ; S D=.45)$. The lowest reported approach to learning was the surface approach $(M=3.04 ; S D=.59)$. 
Table 3

Descriptive Statistics for Students' Approaches to Learning

\begin{tabular}{|c|c|c|c|c|c|c|c|}
\hline & $N$ & $\begin{array}{c}\text { Total Score* } \\
M \pm S D\end{array}$ & $\begin{array}{c}\text { Response** } \\
M \pm S D\end{array}$ & Skew & $\begin{array}{l}\text { Skew } \\
\text { SE }\end{array}$ & Kurtosis & $\begin{array}{c}\text { Kurtosis } \\
\text { SE }\end{array}$ \\
\hline $\begin{array}{l}\text { Deep } \\
\text { Approach }\end{array}$ & 191 & $57.78 \pm 7.24$ & $3.61 \pm .45$ & -.071 & .176 & -.260 & .350 \\
\hline $\begin{array}{l}\text { Strategic } \\
\text { Approach }\end{array}$ & 191 & $74.71 \pm 10.59$ & $3.74 \pm .53$ & -.175 & .176 & -.382 & .350 \\
\hline $\begin{array}{l}\text { Surface } \\
\text { Approach }\end{array}$ & 191 & $48.58 \pm 9.46$ & $3.04 \pm .59$ & -.008 & .176 & -.352 & .350 \\
\hline
\end{tabular}

*Highest possible score: Deep (80), Strategic (100), and Surface (80)

**Likert scale of 1=Strongly Disagree; 2=Disagree, 3=Unsure, 4=Agree, and 5=Strongly Agree

Students' scores for their approaches to learning for deep, strategic, and surface were broken down into four quartiles identified as Low, Middle-Low, Middle-High, and High (Table 4). The highest possible score for the deep approach to learning was 80. Quartile scores for the deep approach were Low $(41-53 ; n=51)$, Middle-Low $(54-58 ; n=47)$, Middle-High $(59-62 ; n=$ 48), and High (63-76; $n=45)$. The highest possible score for the strategic approach to learning was 100. Quartile scores for the deep approach were Low (45-68; $n=53)$, Middle-Low (69-74; $n$ $=43)$, Middle-High $(75-83 ; n=49)$, and High $(84-100 ; n=46)$. The highest possible score for the surface approach to learning was 80. Quartile scores for the deep approach were Low (25-42; $n=51)$, Middle-Low (43-48; $n=48)$, Middle-High (49-56; $n=49)$, and High $(57-73 ; n=43)$.

The ASSIST Inventory asked students to mark their level of agreement with statements about learning from 1-5, with 5 indicating they strongly agree. Therefore, students with lower scores on these approaches indicate utilizing them less, and conversely students with higher scores indicate utilizing these approaches more. Table 4 shows that there are many students in the Middle-High and High scores that are utilizing deep $(n=93)$ and strategic $(n=95)$ approaches to learning. However, the Low and Middle-Low scores indicate there are many students that do not utilize deep $(n=98)$ or strategic approaches $(n=96)$ to learning and the Middle-High and High scores indicate many students are utilizing surface approaches $(n=92)$. While the majority of students in this program reported having a preference for using strategic approaches and deep approaches to their learning, the data suggests there are still many students who use surface approaches to their learning. 
Table 4

Quartile Breakdown for Students' Approach to Learning $(N=191)$

DEEP* STRATEGIC* ${ }^{*}$ SURFACE*

\begin{tabular}{lcccccc} 
& Score & Frequency & Score & Frequency & Score & Frequency \\
\hline Low & $41-53$ & 51 & $45-68$ & 53 & $25-42$ & 51 \\
Middle-Low & $54-58$ & 47 & $69-74$ & 43 & $43-48$ & 48 \\
Middle-High & $59-62$ & 48 & $75-83$ & 49 & $49-56$ & 49 \\
High & $63-76$ & 45 & $84-100$ & 46 & $57-73$ & 43 \\
\hline
\end{tabular}

*Highest possible score: Deep (80), Strategic (100), and Surface (80)

Likert scale of 1=Strongly Disagree; 2=Disagree, 3=Unsure, 4=Agree, and 5=Strongly Agree

RQ2: GPA Impact on Students' Approach to Learning. The second research question asks if students' self-reported cumulative GPA has a relationship with their approach to learning. Students were asked to estimate their cumulative grade point to this point in their college career (Table 5). Responses included: 2.0-2.49 $(n=31), 2.5-2.99(n=54), 3.0-3.49(n=59)$, and 3.5$4.0(n=47)$. Students were grouped into two categories to represent their self-reported GPA: Low GPA (2.0-2.99) and High GPA (3.0-4.0).

Table 5

Students Self-Reported Cumulative GPA and Grouped GPA Categories

\begin{tabular}{lcc|cccc}
\hline \multicolumn{3}{c|}{ Cumulative GPA } & \multicolumn{3}{c}{ Grouped GPA Categories } \\
GPA Range & $n$ & Percent & Category & GPA Range & $n$ & Percent \\
\hline $2.0-2.49$ & 31 & $16.2 \%$ & Low GPA & $2.0-2.99$ & 85 & $44.5 \%$ \\
$2.5-2.99$ & 54 & $28.3 \%$ & & & & \\
$3.0-3.49$ & 59 & $30.9 \%$ & High GPA & $3.0-4.0$ & 106 & $55.5 \%$ \\
$3.5-4.0$ & 47 & $24.6 \%$ & & & & \\
\hline
\end{tabular}

In order to uncover if there was a difference between students' approaches to learning between the Low GPA and High GPA groups, an independent between-groups ANOVA was performed. Deep, strategic, and surface scores for students' approach to learning were normally distributed, as assessed by Shapiro-Wilk's test $(\mathrm{p}>$.05) and a visual inspection of Normal Q-Q Plots. There was no multicollinearity, as assessed by Pearson correlation for students' GPA and strategic strategies $(r=.318 ; p=.000)$, surface strategies $(r=-.214 ; p=.003)$; and deep strategies $(r=.095, p=.190)$. The ANOVA yielded a statistically significant effect for the strategic approach, $\mathrm{F}(1,189)=21.315, p=.000$. Thus students in the Low GPA category 
received lower scores on the strategic approach (70.95) compared to students in the High GPA category (77.72) at significant levels. The ANOVA yielded a statistically significant effect for the surface approach, $\mathrm{F}(1,189)=9.061, p=.003$. Thus students in the Low GPA category received higher scores on the surface approach (50.84) compared to students in the High GPA category (46.77) at significant levels (Table 6). Therefore, it can be said that cumulative GPA and approaches to learning are related.

Table 6

One-Way ANOVA Comparing Approaches to Learning and GPA

\begin{tabular}{lccccccc}
\hline Approach & GPA & $\mathrm{N}$ & Mean & SD & df & F & Sig \\
\hline Deep & Low-GPA & 85 & 57.01 & 7.297 & 190 & 1.733 & .190 \\
& High-GPA & 106 & 58.40 & 7.164 & & & \\
\hline Strategic & Low-GPA & 85 & 70.95 & 10.098 & 190 & 21.315 & $.000^{* *}$ \\
& High-GPA & 106 & 77.72 & 10.034 & & & \\
\hline Surface & Low-GPA & 85 & 50.84 & 9.279 & 190 & 9.061 & $.003 *$ \\
& High-GPA & 106 & 46.77 & 9.258 & & & \\
$* p<.005 ; * * p<.001$ & & & & & & &
\end{tabular}

RQ3: Relationship between Strategic and Deep/Surface Approaches to Learning.

The third research question asks if there is a relationship between the strategic approach to learning and the deep and surface approaches to learning. A Pearson's product moment correlation coefficient was computed to assess the relationship between the strategic approach and the deep/surface approaches to learning. Preliminary analysis showed the relationship to be linear with both variables normally distributed, as assessed by Shapiro-Wilk's test ( $p>.05)$, and there were no outliers. There was a strong (Cohen, 1988) positive correlation between students using the strategic approach to learning and students using the deep approach to learning $[r=$ $0.468, n=191, p=0.000]$. There was a negative moderate (Cohen, 1988) correlation between students using strategic approaches to learning and students using the surface approach to learning $[r=-0.325, n=191, p=0.000]$. In summary, students using strategic approaches to learning were found to be powerful predictors of students using deeper approaches to their learning. In contrast, students with lower scores for their strategic approaches to learning were found to be effective predictors for students that used the surface approach to learning.

\section{Discussion}

As society continues to move toward volatile, uncertain, complex, and ambiguous (VUCA) environments (Carvan, 2015), leadership programs need to be developed so that students move from surface approaches to learning, where they simply memorize content, to deeper approaches to learning (Roberts, 2007). Students need to learn processes to deal with 
wicked problems that do not have straightforward right or wrong solutions (Camillus, 2008). In an effort to determine students' approaches to learning, the ASSIST Inventory was given to students enrolled in an undergraduate Organizational Leadership program at a mid-sized Midwestern university. At first glance, it appears as if more students are using deeper approaches to learning $(M=3.61)$ than surface approaches to learning $(M=3.04)$. However, a more thorough analysis to show the variations in students' scores uncovered the nuances in the data to show a wide distribution in students' approaches to learning scores. Breaking down students' scores into quartiles showed a wide disparity in scores for students. Therefore, while most students are adopting deeper approaches to learning, there are still many students using surface approaches to learning.

Most college instructors would like their students to take deeper approaches to their learning (Weimer, 2012b). It is tempting to put the responsibility of approach to learning entirely on the shoulders of each student. Some would suggest it is the instructor's responsibility to teach and it is the student's responsibility to figure out how to learn. However, our data shows that not all students are using deeper approaches to learning; therefore, it is critical to come up with strategies to help those students using surface approaches to begin adopting deep approaches to learning. Students who are using surface approaches may have deeply ingrained misconceptions about effective learning strategies resulting in habits that are difficult to break. There are several strategies that instructors can employ to help students move toward deep approaches to learning.

\section{Recommendations to Design Classes for Strategic Learning}

Students who are currently using surface approaches to their learning may find it difficult to move directly to deep learning approaches because deep learning can be too conceptual and abstract for students to easily grasp, whereas it may be easier to ask students to develop strategic approaches to their learning first as these are more tactical and concrete. In addition, the data in this study showed a strong positive correlation between students using the strategic approach to learning and students using the deep approach to learning. If instructors want students to use deep approaches to their learning, the first step may be to incorporate opportunities for students to hone their strategic approaches.

The ASSIST Inventory (Tait et al., 1998) identifies five sub-scales related to strategic approaches to learning: (1) organized studying, (2) effective time management, (3) alertness to assessment demands, (4) feelings of ability to achieve, and (5) monitoring their learning effectiveness. Listed are recommendations for instructors to increase student use of these five sub-scales.

Suggestion \#1 - Help Students Organize their Studying. Students who engage in organized studying have effective study skills (Tait et al., 1998). However, research has shown that the number one study strategy used by $84 \%$ of college students is reading and re-reading their notes and/or textbook (Karpicke, Bulter, \& Roediger, 2009), despite it being an inefficient and ineffective strategy for learning (Callender \& McDaniel, 2009). Re-reading causes students to misjudge their knowledge level because they feel comfortable with the information when they re-read and develop fluency illusions (Carey, 2014), which occurs when students believe they know the content better than they do and that future study will not help. 
One strategy students can employ to move from re-reading their notes to more effective learning involves using retrieval practices, which essentially involves testing oneself. Research has found that retrieval practices have a moderately large and statistically significant improvement over other learning conditions $(g=0.61, p<.001)$ (Adesope, 2017). Retrieval practices have proven to be such an effective study strategy because students are deliberately recalling the course content to build stronger neuron connections and identify any existing misperceived fluency levels (Brown, Roediger, and McDaniel, 2014). Karpicke and Roediger (2010) found that students who used repeated retrieval study techniques had a $400 \%$ increase in ideas recalled over students who just read and reread the material. Incorporating retrieval practices will ensure students have durable long-term memories (Karpicke \& Roediger, 2010), which will be needed to develop their deeper learning. Persky and Hudson (2016) suggest that before students can begin to learn more deeply, they need to begin to move away from poor study habits (i.e.- re-reading) which result in short-term recall to highly effective study habits (i.e.- retrieval practices) to build better long term recall in order to transfer their learning to other contexts beyond a pending course examination.

Flash cards. One idea for a retrieval practice involves creating digital flash cards that can be accessed by students on their cell phones or computer devices to repeatedly test themselves on the course content. Instructors can also require students to create their own flash cards and build in time at the start or end of the class for students to quiz each other on course material.

Concept map. Another idea is to have students organize their information into concept maps (Smith \& Weinstein, 2016). They can link different ideas to each other in a visual format, either handwritten or through mind-mapping applications, and describe the relationship between connected concepts. Further, having students share their maps with each other to build a group map may allow students to engage in the retrieval practice together.

Suggestion \#2 - Help Students Develop Better Time Management. Students who have effective time management skills will work steadily on their course studying throughout the semester instead of leaving it to the last minute (Tait et al., 1998). Unfortunately, $51 \%$ of students admit that they wait to study until shortly before their exams to cram (Michaels \& Miethe, 1989). Students get a misperceived sense of accomplishment when they can successfully pass exams within 24 hours of cramming; however, research shows that after one week much of the crammed studying is forgotten (Karpicke \& Roediger, 2010). In order for students to be able to make connections for the course content from start to finish of a class (or entire program), students need to have robust and long lasting memories. Therefore, instructors can design their classes where students are required to implement better time management during the semester instead of waiting to study or write until the day before an exam is scheduled or assignment is due.

Daily quizzes. One strategy to help students with better time management would be to move away from offering infrequent exams such as a mid-term/final assessment and instead implement daily quizzes. Learning management systems provide the ability to offer online quizzes and polling so students can use their cell phone or computer devices to quickly complete these quizzes and get immediate feedback, helping students engage 
in distributed studying. Assessments should not be perceived as "grade-catching mechanisms but instead recognized as enriched learning tools that will have a significant impact on student success" (Weimer, 2017, para. 4).

Project milestones. Instructors can also incorporate frequent assessment with writing assignments. Instead of having a 10 page paper due at the end of the semester, students could turn in small parts of the paper every few weeks. This ensures they are working on the paper over the duration of the course and provides the opportunity to give feedback along the way.

Suggestion \#3 - Help Students Become more Alert to Assessment Demands. Students who are alert to their assessment demands will consider what is required for an assignment before they begin working on it and what the instructor will be looking for (Tait et al., 1998).

Using rubrics. One strategy to help students become alert to assessment demands is to provide rubrics with detailed guidelines about what is expected for each assignment. Students who have used rubrics report that the rubric "helped them focus their efforts, produce work of higher quality, earn a better grade, and feel less anxious about an assignment" (Andrade \& Du, 2005, p. 1). Most learning management systems (i.e. D2L, Blackboard, and Canvas) now include electronic rubrics. This allows students to have a checklist to ensure they have completed all assignment requirements before submission. It also allows instructors to quickly grade student assignments and provide specific feedback.

Grading mock assignments. Beyond simply sharing a rubric with students, instructors can use class time to have students grade a mock assignment with the rubric so they can gain experience and proficiency with the assignment expectations. Offering examples of model assignments can show students how much depth or breath is required.

Suggestion \#4 - Help Students Enhance their Ability to Achieve. Students who have high levels of strategic learning are aware of how well they are achieving and put effort into the course because they are motivated to do well (Tait et al., 1998).

Electronic grade books. One strategy to help enhance students' ability to achieve is through the use of electronic grade books. These offer both instructors and students the ability to see individual assignment grades and cumulative progress in the course, helping students plan out their course work for the remainder of the term.

Student interaction. Research has shown that many students have a misperceived fluency illusion (Carey, 2014), and seldom come to visit their professors during scheduled office hours (Bippus, Kearney, Plax, \& Brooks, 2003; Kuh \& Hu, 2001). This can be problematic for students who may be struggling in class. Learning management systems can now automatically identify students who are not meeting grade expectations so instructors can reach out to help them develop strategies to get back on track.

Interactions between students and instructors has been shown to have positive benefits on students' academic accomplishments, level of satisfaction and retention, and intellectual and personal growth (Cotton \& Wilson, 2006). 
Suggestion \#5 - Help Students Monitor their Progress in the Course. Students who monitor their effectiveness give thought to an assignment before beginning work to make sure they know how to best tackle it as well as review their work when they are complete to ensure they have met all the assignment requirements (Tait et al., 1998).

Re-writes. Instructors can help students monitor their progress by developing formative assignments that allow students to redo or take feedback for future assignments. If students are required to use the instructor feedback from previous assignments, they may take the time to review and understand the instructor feedback. On the other hand, if assignments are summative, where none of the instructor feedback applies to future assignments, many students will often not take the time to review past feedback. Research on the use of formative assignments has been shown to increase students' achievement and motivation because students believe they have the ability to take feedback and continually improve their efforts (Cauley \& McMillan, 2010).

\section{Recommendation to Design Classes for Deeper Learning}

One of the primary goals of higher education is to help students develop deep approaches to their learning (Entwistle, 2009). Getting students to engage in deep learning approaches will require them to move from simply taking notes and passing tests to assuming more responsibility for their learning. Students may resist moving to deep learning as it will require more effort, require them to learn new forms of learning, and change years of deeply developed learning habits (Doyle, 2008). The ASSIST Inventory (Tait et al., 1998) identifies four sub-scales that can be used to identify practices associated with deep approaches to learning: (1) seeking meaning, (2) relating ideas, (3) use of evidence, and (4) interest in ideas. Below are specific recommendations to incorporate deep learning into courses.

Suggestion \#1- Help Students Seek Meaning. Students who seek meaning will try to understanding the course content, make sense of what they are learning, build meaning, and make ideas their own (Tait et al., 1998). These behaviors are reflective of metacognition, which is the process of thinking about one's thinking. Students who have higher levels of metacognition will attempt to seek out and understand the meaning of what they are learning. In addition, they are better able to transfer the content, processes, and skills learned to different contexts (Fadel, Trilling, \& Bialik, 2015).

Instructor metacognitive sharing. Instructors should share their own metacognitive strategies with their students by continually including their own think-outloud learning strategies with the class. These think-out-loud discourses should explicitly articulate the instructor's personal processes toward using strategic and deeper approaches (Duplass, 2006). Research has shown that students can adopt more effective instructional strategies when they are permitted to observe a teacher's thought process because students can then imitate effective approaches to learning (Bandura, 1986).

Reflections. Another way to help students enhance their metacognition is by having them engage in reflections. These activities require students to think about their own thinking processes in which they are able to evaluate their own study habits for the future (Weimer, 2012a). 
Class preparation reflection. Having students write robust reflections on their approaches to learning can help with metacognition. For example, have students take a few minutes at the start of class to write in their notes about things they did to prepare for class such as having done the reading, thought about the content, and completed homework assignments. Have a few students share their class preparation activities with the rest of the class so the other students can compare their preparation activities with those of other students.

Notes reflection. Another activity includes asking students to write questions they have about the content in their notes. This will get students prepared and actively listening to answer those questions.

Observation reflection. Lastly, another activity would be to ask students to consider what caused them to miss specific questions on a quiz or miss points on an assignment by writing a short observation.

Suggestion \#2 - Help Students Relate Ideas. Students who relate ideas will try to make connections from course content to other disciplines, topics, and reading materials outside the course (Tait et al., 1998). One strategy is for instructors to move away from coverage teaching (Wiggins \& McTighe, 2011) where they design courses that include as much content as they can possibly jam-pack over the teaching term. Coverage teaching results in classes that teach a series of discrete facts that can make it difficult for students to make connections.

Big idea. Instructors should use the backward design to develop their courses so that they have a big idea that drives all course design decisions (Wiggins \& McTighe, 2011). The big idea should serve as the conceptual glue to help hold the course together (Huston, 2009) and should be clearly communicated to students and reinforced throughout the semester. Kelting-Gibson (2005) found that instructors who use the backward design have students that can connect the course content with other meaningful topics to promote deeper approaches to learning.

Suggestion \#3 - Provide Students the Opportunity to Use Evidence. Students who use evidence do not take things at face value and question their current beliefs to reach new and informed decisions (Tait et al., 998). However, students who use surface learning will hold on to their own cognitive bias due to unrepresentative personal experiences (Thaler \& Sunstein, 2008). Courses that do not include critical feedback to help students identify their misconceptions will simply result in students confirming their flawed personal beliefs.

Community of inquiry. Instructors need to design their classes where students are given opportunities to work in a Community of Inquiry (CoI) that pushes them out of their "intellectual comfort zone" (Garrison, 2017, p. 13) to challenge their personal biases. Students who are exposed to multidisciplinary perspectives and engage in thoughtful discourse will begin to use evidence to examine their flawed beliefs to reach more informed decisions, leading them to deeper approaches to their learning (Garrison, 2017). 
Suggestion \#4 - Enhance Students' Interest in Ideas. Students who have an interest in ideas will get excited about the course content as well as continue to examine the content and think about the ideas from class afterwards (Tait et al., 1998). Instructors can increase students' interest in the course by making a strong connection from the course material to students' everyday lives. This allows students to find relevance to the course material and it increases their engagement and motivation (Martin \& Dowson, 2009). By providing utility value, instructors can emphasize how the content will have importance for the students' short-term and long-term goals (Ormrod, 2006).

Real world examples. Instructors can make content more relevant by providing real world examples, inviting guest speakers, having students interview outside experts, and incorporating authentic case studies.

Application assignment. Another activity includes a short self-reflection for each assignment that asks students to make connections from the assignment to their personal and/or professional lives. This will require students to look at course content from a deeper and more personal perspective and may result in an increased interest in a course topic.

\section{Study Limitations}

There are four primary limitations of this study. First, this study only included a small number of students from one program in one institution, making the findings not generalizable across other programs or institutions. Nonetheless, the recommendations for helping students move to strategic and to deep learning approaches may be useful for faculty members as they grapple with helping their students engage in deep learning.

Second, the students in this study were asked to identify the learning strategies they use in college; not just in leadership courses. Without assessing for contextual application, it is hard to know if some students use surface approaches in some classes and not others, meaning that they could engage in deep learning in their leadership courses but not in their math classes.

Third, due to the Hollywood Effect, survey respondents are more likely to rate themselves higher for behavior they believe is more desirable (Rosch and Schwartz, 2009). Because it might appear that deep learning is the preferred approach over surface learning, some students may have self-reported their approaches to learning that veered toward the deeper approach in an effort to give the perceived right response.

Finally, the ASSIST Inventory was developed for use in Britain. The verbiage in the survey needed to be modified to be appropriate for students in America. While the changes made were minor, the updates could have had an impact on the reliability of the instrument.

\section{Areas for Future Research}

The data in this research study was gathered in a quantitative format. Therefore, the 
researchers were only able to provide a descriptive snapshot of learning approaches used by students. Measurements about frequency of use, context, and even comfort with various approaches were not included. Follow-up research could include additional quantitative studies measuring these constructs. In addition, focus groups or interviews with students could provide qualitative data to substantiate and explain quantitative findings.

Because the data collected for this study was gathered in one program at one institution, a suggested area for further study would be to gather data from students in different programs or institutions to compare results.

\section{Conclusion}

This study found that students in an undergraduate Organizational Leadership program use a variety of approaches to learning. But, given the call for deeper learning in leadership and the need for leaders to be able to solve the world's wicked problems, it is critical for faculty members to design courses that help students practice deep learning today, so they are ready for the complexity of leadership tomorrow (Mihel, 2010).

\section{References}

Adesope, O. O. (2017). Rethinking the use of tests: A meta-Analysis of practice testing. Review of Educational Research, 1-45. Retrieved from http://journals.sagepub.com/doi/pdf/10.3102/0034654316689306

Andenoro, A. C., Allen, S. J., Haber-Curran, P., Jenkins, D. M., Sowcik, M., Dugan, J. P., \& Osteen, L. (2013). National leadership education research agenda 2013-2018: Providing strategic direction for the field of leadership education. Retrieved from Association of Leadership Educators website: http://leadershipeducators.org/

Andrade, H. \& Du, Y. (2005). Student perspectives on rubric-referenced assessment. Practice Assessment, Research \& Evaluation, 3(10), 1-11.

Andrews, J., Garriso, D. R., \& Magnusson, K. (2006). The teaching and learning transaction in higher education: A study of excellent professors and their students. Teaching in Higher Education, 1(1), 81-103. doi: http://dx.doi.org/10.1080/1356251960010107

Bandura, A. (1986). Social foundations of thought and action: A social cognitive theory. Englewood Cliffs, NJ: Prentice Hall.

Biggs, J. B. (1987). Student approaches to learning and studying. Hawthorn: Australian Council for Educational Research Limited. Retrieved from http://files.eric.ed.gov/fulltext/ED308201.pdf 
Biggs, J. B. (1994). Approaches to learning: Nature and measurement of. In T. Husen and T. N. Postlethwaite (Eds.), The international encyclopedia of education ( $2^{\text {nd }}$ ed., Vol. 1) (pp. 319-322). Oxford: Pergamon.

Biggs, J. (1999) Teaching for quality learning at university. SRHE \& Open University Press.

Bippus, A. M., Kearney, P., Plax, T. G., \& Brooks, C. F. (2003). Teacher access and mentoring abilities: Predicting the outcome value of extra class communication. Journal of Applied Communication Research, 31(3), 260-275. doi: 10.1080/00909880305379

Brown, P. C., Roediger, H. L, \& McDaniel, M. A. (2014). Making it stick: The science of successful learning. Cambridge, MA: The Belknap Press of Harvard university Press.

Brungardt, C. L., Greenleaf, J. P., Brungardt, C. J., \& Arensdorf, J. (2006). Majoring in leadership. A review of undergraduate leadership degree programs. Journal of Leadership Education, 5(1), 4-25.

Byrne M., Flood B., \& Willis P. (2004). Validation of the approaches and study scales inventory for students (ASSIST) using accounting students in the USA and Ireland: A research note. Accounting Education, 13(4), 449-459. doi: http://dx.doi.org/10.1080/0963928042000306792

Callender, A. A. \& McDaniel, M. A. (2009). The limited benefits of rereading educational texts. Contemporary Educational Psychology, 34(1), 30-41.

Camillus, J. C. (2008). Strategy as a wicked problem. Harvard Business Review, 98-106.

Carey, B. (2014, September 4). Why flunking exams is actually a good thing. New York Times Magazine. Retrieved from http://www.nytimes.com/2014/09/07/magazine/why-flunkingexams-is-actually-a-good-thing.html

Carvan, M. T. (2015). Leadership education for the volatile, uncertain, complex, and ambiguous now: A challenge to the field. Journal of Leadership Education, 14(4), 3-10. doi: 1012806/V14/I4/C2

Cauley, K., \& McMillan, J. (2010). Formative assessment techniques to support student motivation and achievement. Journal of Educational Strategies, 83 (1), 1-6.

Chan, J., Fu, K., Schunn, C., Cagan, J., Wood, K., Kotovsky, K. (2011). On the benefits and pitfalls of analogies for innovative design: Ideation performance based on analogical distance, commonness, and modality. Journal of Mechanical Design,133(081004), 1-11.. DOI: $10.1115 / 1.4004396$

Cohen, J. (1988). Statistical power analysis for the behavioral sciences (2nd edition). Hillsdale, NJ: Lawrence Erlbaum Associates. 
Cotten, S. R., \& Wilson, B. (2006). Student-faculty interactions: Dynamics and determinants. Higher Education, 51(3), 487-519.

CRLI (1997). ASSIST - Approaches and study skills inventory for students. Edinburgh: University of Edinburgh.

DeVellis, R. F. (2012). Scale development: Theory and applications. Los Angeles: Sage.

Dong, Y., \& Peng, C.-Y. J. (2013). Principled missing data methods for researchers. SpringerPlus, 2(2013), 222. doi: http://doi.org/10.1186/2193-1801-2-222

Doyle, T. (2008). Helping students learn in a learner-centered environment: A guide to facilitating learning in higher education. Sterling, VA: Stylus.

Duff, A. (2004). Understanding academic performance and progression of first year accounting and business economics undergraduates: The role of approaches to learning and prior academic achievement. Accounting Education: An International Journal, 13(4), 409-430.

Duplass, J. (2006). Middle and high school teaching: Methods, standards, and best practices. Boston: Houghton Mifflin Company.

Fadel, C., Trilling, B., \& Bialik, M. (2015). Four-dimensional education: The competencies learners need to succeed. Boston, MA: The Center for Curriculum Redesign.

Entwistle, N. (2000, November). Promoting deep learning through teaching and assessment: conceptual frameworks and educational contexts. Paper presented at the TLRP Conference, Leicester, November 2000. Retrieved from http://www.etl.tla.ed.ac.uk/docs/entwistle2000.pdf

Entwistle, N. (2009). Teaching for understanding at university: Deep approaches and distinctive ways of thinking. Basingstoke: Palgrave Macmillan.

Entwistle N., McCune V., \& Walker P. (2001). Conceptions, styles and approaches within higher education: Analytic abstractions and everyday experience. In R. J. Sternberg and L. F. Zhang (Eds.), Perspectives on thinking, learning, and cognitive styles (pp. 103-136). Mahwah, NJ: Lawrence Erlbaum.

Entwistle, N. J., \& Peterson, E. R. (2004). Conceptions of learning and knowledge in higher education: Relationships with study behaviour and influences of learning environments. International Journal of Educational Research, 41(6), 407-428. Retrieved from http://www.sciencedirect.com/science/article/pii/S0883035505000571

Entwistle N, Tait, H., and McCune, V. (2000). Patterns of response to an approaches to studying inventory across contrasting groups and contexts. European Journal of the Psychology of Education, XV(1), 38. 
Garrison, D. R. (2017). E-learning in the $21^{\text {st }}$ century: A community of inquiry framework for research and practice. New York, NY: Routledge.

Huston, T. (2009). Teaching what you don't know. Cambridge, MA: Harvard University Press.

ILA. (2009). Guiding questions: Guidelines for leadership education programs. Retrieved from http://www.ila-net.org/communities/LC/GuidingQuestionsFinal.pdf

Karpicke, J. D., Butler, A. C., \& Roediger, H. L. (2009). Metacognitive strategies in student learning: Do students practice retrieval when they study on their own? Memory, 17 (4), 471-470.

Karpicke, J. D., \& Roediger, H. L. (2010). Repeated retrieval during learning is the key to longterm retention Journal of Memory and Language, 57, 151-162.

Kellerman, B. (2004). Bad leadership. Boston: Harvard Business School Press.

Kelting-Gibson, L. M. (2005). Comparison of curriculum development practices. Educational Research Quarterly, 29, 26-36.

Kuh, G. D. \& Hu, S. (2001). The effects of student-faculty interaction in the 1990s. Review of Higher Education, 24(3), 309-332.

Martin, A.J., \& Dowson, M. (2009). Interpersonal relationships, motivation, engagement, and achievement: Yields for theory, current issues, and educational practice. Review of Educational Research, 79, 327-365.

Marton, F., Hounsell, D., and Entwistle, N. (1997) The experience of learning: Implications for teaching and studying in higher education. Edinburgh: Scottish Academic Press.

Marton, F., \& Säljö, R. (1976). On qualitative differences in learning: 1-outcome and process. British Journal of Educational Psychology, 46, 4-11.

May, W., Chung, E.K., Elliot, D., \& Fisher, D. (2012). The relationship between medical students' learning approaches and performance on a summative high-stakes clinical performance examination. Medical Teacher, 34(4), 236-241. doi: http://dx.doi.org/10.3109/0142159X.2012.652995

Michaels, J. W., \& Miethe, T. D. (1989). Academic effort and college grades. Social Forces, 68(1), 309-319.

Mihel, G. (2010). Higher education's future: Traditions to embrace, discard, and alter. Journal of Leadership Studies, 4(1), 72-73. doi: 10.1002/jls

Ormrod, J.E. (2006). Educational psychology: Developing learners (5th ed.). Upper Saddle River, N.J.: Pearson Education, Inc. 
Persky, A. M., \& Hudson, S. L. (2016). A snapshot of student study strategies across a professional pharmacy curriculum: Are students using evidence-based practice? Currents in Pharmacy Teaching and Learning, 8(2), 141-147.

Petrie, N. (2014). Future trends in leadership development. Colorado Springs, CO: Center for Creative Leadership.

Phan, H. P., \& Deo, B. (2007). The revised learning process questionnaire: A validation of a Western model of students' study approaches to the South Pacific context using confirmatory factor analysis. British Journal of Educational Psychology, 77, 719.

Pintrich, P. R., \& Garcia, T. (1991). Student goal orientation and self-regulation in the college classroom. In M. Maehr, \& P. R. Pintrich (Eds.), Advances in motivation and achievement: Goals and self-regulatory processes (pp. 317-402). Greenwich, CT: JAI.

Prosser, M, \& Trigwell, K. (1999) Understanding learning and teaching: The experience in Higher Education. Buckingham, England and Philadelphia, PA: Society for Research into Higher Education and Open University Press.

Roberts, D. (2007). Deeper learning in leadership: Helping college students find the potential within. San Francisco, CA: Wiley \& Sons, Inc.

Rosch, D. M., \& Schwartz, L. M. (2009). Potential issues and pitfalls in outcomes assessment in leadership education. Journal of Leadership Education, 8(1), 177-194.

Smith, M., \& Weinstein, Y. (2016). Learn how to study using...retrieval practice. Retrieved from http://www.learningscientists.org/blog/2016/6/23-1

Stanger-Hall, K. F. (2012). Multiple-Choice Exams: An Obstacle for Higher-Level Thinking in Introductory Science Classes. CBE Life Sciences Education, 11(3), 294-306. http://doi.org/10.1187/cbe.11-11-0100

Tait, H., Entwistle, N. J., \& McCune, V. (1998). ASSIST: A re-conceptualization of the Approaches to Studying Inventory. In C. Rust (Ed.), Improving students as learners (pp. 262-271). Oxford: Oxford Brookes University, Centre for Staff and Learning Development.

Thaler, R. H., \& Sunstein, C. R. (2008). Nudge: Improving decisions about health, wealth, and happiness. New Haven, CT: Yale University Press.

Vermunt, J. D. (1998). The regulation of constructive learning processes. British Journal of Educational Psychology, 68(2), 149-171. doi: 10.1111/j.2044-8279.1998.tb01281.x

Weimer, M. (2012a, October 31). Teaching metacognition to improve student learning. Magna Faculty Focus. Retrieved from http://www.facultyfocus.com/articles/teaching-professorblog/teaching-metacognition-to-improve-student-learning/ 
Weimer, M. (2012b, November 19). Deep learning vs. surface learning: Getting students to understand the difference. Magna Faculty Focus. Retrieved from http://www.facultyfocus.com/articles/teaching-professor-blog/deep-learning-vs-surfacelearning-getting-students-to-understand-the-difference/

Weimer, M. (2017). An integrated approach to student exams. Magna Online Seminar Live. Retrieved from http://www.magnapubs.com/online-seminars/an-integrated-approach-tostudent-exams-14335-1.html

Wiggins, G., \& McTighe, J. (2011). The understanding by design guide to creating high-quality units. Alexandria, VA: ASCD.

Woods, D. R. (1994). Problem-based learning: How to gain the most from PBL. Watertown, Ontario: Donald R. Woods.

\section{Author Biographies}

Sheri Stover, Ph.D. (sheri.stover@wright.edu) is an Associate Professor in the Leadership Studies in Education and Organizations department at Wright State University. She is the Program Director for the Instructional Design for Digital Learning (IDDL) program. She has many Quality Matters certifications and won several awards including Scholarship and Teaching.

Corey Seemiller, Ph.D. (corey.seemiller@wright.edu) is a faculty member in the Department of Leadership Studies in Education and Organizations at Wright State University. She is the author of The Student Leadership Competencies Guidebook, Generation Z Goes to College, and Generation Z Leads. 